\title{
Oridonin induces apoptosis through the mitochondrial pathway in human gastric cancer SGC-7901 cells
}

\author{
SHIYONG GAO ${ }^{1 *}$, HUIXIN TAN $^{2 *}$, NAN ZHU $^{3}$, HAIYU GAO $^{1}$, CHUNYU LV $^{1}$, JIAN GANG ${ }^{1}$ and YUBIN JI ${ }^{1}$ \\ ${ }^{1}$ The Institute of Materia Medica, The Research Center of Life Sciences and Environmental Sciences, \\ Harbin University of Commerce, Harbin 150076; ${ }^{2}$ Department of Pharmacy, The Fourth Affiliated Hospital of \\ Harbin Medical University, Harbin 150001; ${ }^{3}$ Engineering Research Center of Natural Anticancer Drugs of \\ Ministry of Education, Harbin University of Commerce, Harbin 150076, P.R. China
}

Received February 11, 2016; Accepted March 21, 2016

DOI: $10.3892 /$ ijo.2016.3479

\begin{abstract}
Oridonin is one of the most important antitumor active ingredients of Rabdosia rubescens. Recently published studies from our laboratory have demonstrated that oridonin was able to arrest human gastric cancer SGC-7901 cells at $\mathrm{G}_{2} / \mathrm{M}$ phase. However, little is known about inducing apoptosis in gastric cancer. The aim of this study was to investigate the effect of oridonin on antineoplastic capability of SGC-7901 cells and the detailed molecular mechanism of oridoninmediated intrinsic pathway of apoptosis. Cell proliferation was assessed by MTT assay while apoptosis induced by oridonin was determined by Hoechst 33342 staining assay and Annexin V/PI double staining assay. Early apoptotic rate was stained by Annexin V/PI and detected by flow cytometry. Apoptosis pathway was analyzed by western blot analysis of Bcl-2, Bax, cytochrome $\mathrm{c}$ and caspase- 3 expression. The results showed that oridonin was able to inhibit the SGC-7901 cell proliferation, the 50\% growth inhibition $\left(\mathrm{IC}_{50}\right)$ was $22.74 \mu \mathrm{M}$. Oridonin could induce cell apoptosis of SGC-7901 cells and the early apoptotic rates induced by 0,20 , $40,80 \mu \mathrm{mol} / 1$ oridonin were $1.53 \pm 0.67,3.33 \pm 0.29,84.80 \pm 0.82$ and $96.43 \pm 0.51 \%$, respectively. Western blot analysis revealed that oridonin downregulated $\mathrm{Bcl}-2$ protein (the anti-apoptotic factor) and upregulated Bax protein (pro-apoptotic factor),
\end{abstract}

Correspondence to: Ms Huixin Tan, Department of Pharmacy, The Fourth Affiliated Hospital of Harbin Medical University, 37 Yiyuan Street, Nangang District, Harbin, Heilongjiang 150001, P.R. China

E-mail: thxydsy@163.com

Dr Shiyong Gao, The Institute of Materia Medica, The Research Center of Life Sciences and Environmental Sciences, Harbin University of Commerce, 138 Tongda Street, Daoli District, Harbin, Heilongjiang 150076, P.R. China

E-mail: sygao2002@163.com

\section{${ }^{*}$ Contributed equally}

Key words: oridonin, apoptosis, mitochondrial pathway, human gastric cancer eventually leading to a reduction in the ratio of $\mathrm{Bcl}-2 / \mathrm{Bax}$ proteins. Furthermore, oridonin induced the release of cytochrome $\mathrm{c}$ from the mitochondria to the cytosol and the activation of caspase-3. Taken together, the current study suggested that oridonin induced apoptosis in SGC-7901 cells via the mitochondrial signal pathway, which may represent one of the major mechanisms of oridonin-mediated apoptosis in SGC-7901 cells.

\section{Introduction}

Gastric cancer is one of the most common malignant tumors worldwide. In less developed countries, stomach cancers are also leading causes of cancer death, which is generally about twice as high in men as in women (1). The incidence and mortality rates vary widely across countries, the highest in high-income Asia Pacific, east Asia, and Andean Latin America (2), which was related to dietary patterns, food storage, and the availability of fresh produce.

Chemotherapy is widely used in cancer treatment, it shows better therapy effect, but toxic and side effects cause serious harm to cancer patients. Recently, research interest has turned to the traditional medicine, and investigations of new anticancer drugs with low toxicity. Rabdosia rubescens, a medical plant, has been used to treat cancer in China for a long time (3), and has been reported to show better effects in the treatment of urinary bladder carcinoma (4), esophageal carcinoma $(5,6)$, prostate cancer $(7)$, and oridonin is one of the most important antitumor active ingredient of Rabdosia rubescens $(8,9)$.

Oridonin, molecular formula $\mathrm{C}_{20} \mathrm{H}_{28} \mathrm{O}_{6}$ (Fig. 1), is a diterpenoid compound (10). Previous studies have shown that oridonin has antitumor activities in vivo and in vitro (11-13), and oridonin inhibited proliferation of cancer cells by inducing autophagic pathways (14-18), arresting the cell cycle on $\mathrm{G}_{0} / \mathrm{G}_{1}$ phase (19) or $\mathrm{G}_{2} / \mathrm{M}$ phase (20-24), inducing apoptosis of human laryngeal cancer cells (25), esophageal cancer (26), colorectal carcinoma (27), pancreatic cancer (28), hepatocellular carcinoma (29,30). However, few reports exist on oridonin-induced apoptosis on gastric cancer. Therefore, this study explored apoptosis and related protein expression induced by oridonin on human gastric cancer SGC-7901 cells. 


\section{Materials and methods}

Chemicals and other reagents. Oridonin (>98\%) was purchased from National Institutes for Food and Drug Control (Beijing, China). Doxorubicin was obtained from Pharmacia Italia S.p.A., Gaggiano, Italy. Hydroxycamptothecin (HCPT) was provided by Shanghai Longxiang Biological Medicine Development Co. Ltd. (Shanghai, China). Dimethyl sulfoxide (DMSO), trypsin, Tris, glycine, acrylamide, methylene diacrylamide and Tween-20 were purchased from Sigma-Aldrich (St. Louis, MO, USA). RPMI-1640 cell culture medium was purchased from Gibco (Grand Island, NY, USA). Fetal calf serum (FCS) was purchased from Sijiqing Hangzhou Bio Engineering Co., Ltd. (Hangzhou, China). Hoechst33342, Annexin V-FITC apoptosis detection kit, DAB Horseradish Peroxidase Color Development kit were obtained from the Beyotime Institute of Biotechnology (Jiangsu, China). Antibodies for cytochrome c, Bcl-2, Bax, caspase- 3 , cleaved-caspase- $3, \beta$-actin, and the secondary antibodies were purchased from ZSGB-BIO (Beijing, China). All other chemicals and solvents used were the highest purity grade.

Cell line and culture conditions. The human gastric cancinoma SGC-7901 cell line was obtained from American Type Culture Collection (Manassas, VA, USA). The cells were cultured in RPMI-1640 supplement with $10 \%(\mathrm{v} / \mathrm{v})$ fetal bovine serum (FBS) and antibiotics (100 IU/ml of penicillin and $100 \mu \mathrm{g} / \mathrm{ml}$ of streptomycin) at $37^{\circ} \mathrm{C}$ in a humidified atmosphere containing $5 \% \mathrm{CO}_{2}$.

Cell viability and cytotoxicity. The cultured cells at the exponential growth phase were harvested from the culture flasks by trypsin and then re-suspended in fresh RPMI-1640 medium. The cell suspensions were dispensed into a 96 -well microplate at $100 \mu \mathrm{l} /$ well and placed in an incubator with $5 \% \mathrm{CO}_{2}$ at $37^{\circ} \mathrm{C}$. After $24 \mathrm{~h}, 100 \mu \mathrm{l}$ various concentrations of oridonin were added and incubated for $72 \mathrm{~h}$. Then the medium was discarded and $100 \mu \mathrm{l}$ of MTT stock solution $(1 \mathrm{mg} / \mathrm{ml})$ was added. After incubation for $4 \mathrm{~h}$, DMSO $(150 \mu \mathrm{l})$ was added to each well to solubilize the water-insoluble purple formazan crystals. The amount of MTT-formazan is directly proportional to the number of living cells and was determined by measuring the optical density (OD) at $570 \mathrm{~nm}$ using microplate reader (model 680; Bio-Rad Laboratories, Hercules, CA, USA). The percentage of cytotoxic activity compared to the untreated cells was determined, and the $\mathrm{IC}_{50}$ was calculated by the Logit method.

Cell nuclear morphology observation (Hoechst 33342). Morphology of apoptotic cell was observed by Hoechst 33342 staining assay. The cells were washed in phosphate-buffered saline (PBS) and fixed in formaldehyde solution (4\%, $\mathrm{w} / \mathrm{v})$ for $30 \mathrm{~min}$. Then the fixed cells were stained with $10 \mathrm{mg} / \mathrm{ml}$ Hoechst 33342 for $10 \mathrm{~min}$, and nuclear morphology was observed under a fluorescence microscopy (Leica, Wetzlar, Germany) equipped with a digital camera.

Confocal laser scanning microscopy assay. Qualitative experiment of apoptosis was observed by confocal laser scanning microscopy after staining cells with the Annexin V-FITC apoptosis detection kit (MultiSciences Biotech Co., Ltd.,

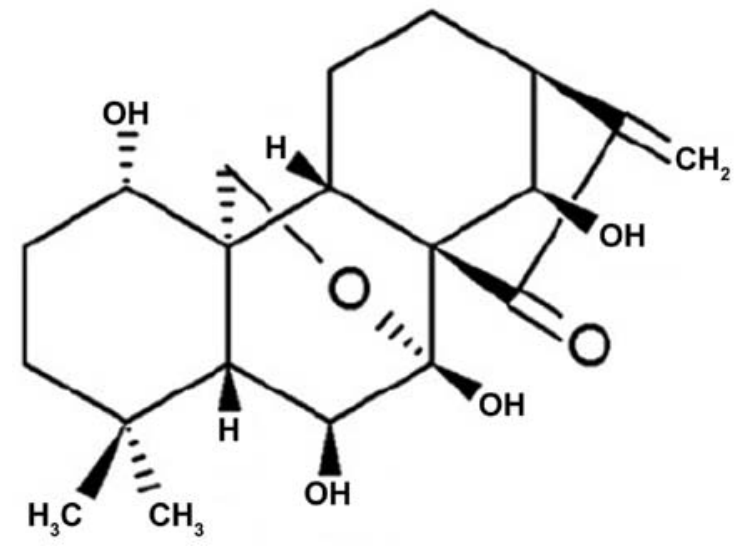

Figure 1. Structure of oridonin.

Hangzhou, China). SGC-7901 cells $\left(1.5 \times 10^{5}\right.$ cells/well) were placed on 6-well plates and incubated with oridonin for $24 \mathrm{~h}$. The cells were stained by Annexin V-FITC (green fluorescence) in the dark for phosphatidylserine (PS) examination. Then cells were stained with PI (red fluorescence) in the dark for nucleus examination. Stained cells were visualized by confocal laser scanning microscopy (Leica, SP2, Wetzlar, Germany) equipped with $488 \mathrm{~nm}$ Argon lasers (31).

Flow cytometric analysis of apoptosis. Early apoptosis rate were measured using the Annexin V-FITC apoptosis detection kit (MultiSciences Biotech Co. Ltd., China) as described in the supplier instructions. After exposure to oridinin $(0,20$, 40 and $80 \mu \mathrm{M}$ ) for $24 \mathrm{~h}$, cells were harvested by centrifugation, washed twice with PBS, and resuspended in Binding Buffer, $5 \mu 1$ of Annexin V-FITC and $5 \mu 1$ of propidium iodide (PI, $50 \mathrm{mg} / \mathrm{ml}$ ) was added and incubated at room temperature in the dark. The data acquisition and analysis were performed using MultiCycle software flow cytometry (Beckman Coulter, XL, USA).

Total protein extraction and western blot assay. SGC-7901 cells were treated with different concentration of oridonin. For isolation of total protein fractions, cells were collected, washed twice with cold PBS, and lysed with cell lysis buffer (50 mM Tris-Cl, pH 8.0, $120 \mathrm{mM} \mathrm{NaCl}, 50 \mathrm{mM} \mathrm{NaF}, 200 \mu \mathrm{M}$ sodium vanadate, $0.5 \% \mathrm{NP}-40,10 \mathrm{mM}$ phenylmethylsulfonyl fluoride (PMSF), $2 \mu \mathrm{g} / \mathrm{ml}$ aprotinin $0.2 \mu 1,10 \mu \mathrm{g} / \mathrm{ml}$ leupeptin $10 \mu \mathrm{l})$. The lysates were centrifuged at $12000 \mathrm{x} \mathrm{g}$ for $10 \mathrm{~min}$ at $4^{\circ} \mathrm{C}$, the supernatant was saved at $-20^{\circ} \mathrm{C}$. Protein concentrations of cell lysates were detected by Bradford assay (32). Total protein samples were separated by SDS-PAGE. The separated proteins were transferred to NC membranes. After being blocked with blocking solution (5\% skim milk in TBS, $10 \mathrm{mM}$ Tris-HCl, $150 \mathrm{mM} \mathrm{NaCl}, \mathrm{pH} 7.5$ plus $0.1 \%$ Tween-20) at room temperature for $2 \mathrm{~h}$. Each membrane was incubated with primary antibodies overnight at $4^{\circ} \mathrm{C}$. Afterwards, the membranes were probed with the appropriate horseradish-peroxidase conjugated secondary antibody for $2 \mathrm{~h}$ at room temperature. Detection was performed by the DAB Horseradish Peroxidase Color Development kit (Beyotime Institute of Biotechnology) according to the manufacturer's instructions. Bands were recorded and relative density units 
Table I. Doses inducing 50\% cell growth inhibition $\left(\mathrm{IC}_{50}\right)$ of oridonin against human gastric cancer SGC-7901 cells.

\begin{tabular}{lc}
\hline Groups & $\mathrm{IC}_{50}(\mu \mathrm{M})$ \\
\hline Oridonin & 22.74 \\
Hydroxycamptothecin & 17.46 \\
\hline
\end{tabular}

of the bands were analyzed by Gel Imaging System (Tanon, GIS-2019, Beijing, China). Densitometrical data of multiple experiments are shown.

Statistical analysis. The data are presented as the mean $\pm \mathrm{SD}$. Statistical significance was calculated using Student's t-test. P-values of $\leq 5 \%$ were considered to indicate statistically significant differences.

\section{Results}

Effect of oridonin on SGC-7901 cell viability. In order to evaluate the effect of oridonin on proliferation of the SGC-7901 cells, the cells were treated with different concentrations of oridonin for $72 \mathrm{~h}$, the cell viability was quantitated by MTT assay. The results showed that oridonin inhibited the proliferation of SGC-7901 cells, and the $\mathrm{IC}_{50}$ was $22.74 \mu \mathrm{M}$. The results are shown in Table I.

Effect of oridonin on SGC-7901 cell nuclei morphology. The results above can significantly demonstrate that oridonin possessed notable antitumor activity on human gastric cancer SGC-7901 cells. To determine whether the antitumor activity of oridonin was due to induction of apoptosis, SGC-7901 cells were stained with Hoechst 33342 to examine the nuclear morphological changes. The results showed that cells of the control group had normal nuclear morphology and the dye of Hoechst 33342 was evenly distributed under fluorescent microscope, which indicated that the chromatin was equivalently distributed in the nucleus. However, after treatment with different concentrations of oridonin for $24 \mathrm{~h}$, the characteristic features of apoptosis (including marked nuclear fragmentation, nuclear blebbing, condensation of chromatin, and emitting brighter fluorescence) was clearly detected in the SGC-7901 cells under the inverted fluorescence microscope (Fig. 2Ac-e). These results indicated that oridonin induced cell apoptosis in human gastric carcinoma.

Effect of oridonin on SGC-7901 cell membrance morphology. In order to confirm whether oridonin induced cell apoptosis, we applied the assay of Annexin V-FITC stain for detection of phosphatidylserine (PS), the biochemical marker of apoptosis. PS is normally located in the inner plasma membrane, however, in the early apoptosis the PS is transferred to its outer surface. Annexin V-FITC combined with PS of the outer surface of the membrance and emit green fluorescent. After treatment with different concentrations of oridonin for $24 \mathrm{~h}$, SGC-7901 cells were stained by Annexin V-FITC (green fluorescence) and PI (red fluorescence), and observed and photographed by laser scanning confocal microscopy.
Table II. Oridonin-induced cell apoptotic rate on SGC-7901 cells.

\begin{tabular}{lccc}
\hline Group & $\begin{array}{c}\text { Dosage } \\
(\mu \mathrm{M})\end{array}$ & $\begin{array}{c}\text { Early apoptotic } \\
\text { rate }(\%)\end{array}$ & $\begin{array}{c}\text { Late apoptotic } \\
\text { rate }(\%)\end{array}$ \\
\hline Control & - & $1.53 \pm 0.67$ & $0.70 \pm 0.20$ \\
Doxorubicin & 7 & $32.33 \pm 1.68^{\mathrm{b}}$ & $27.60 \pm 2.65^{\mathrm{b}}$ \\
Oridonin & 20 & $3.33 \pm 0.29$ & $0.73 \pm 0.12$ \\
Oridonin & 40 & $84.80 \pm 0.82^{\mathrm{b}}$ & $4.83 \pm 0.25$ \\
Oridonin & 80 & $96.43 \pm 0.51^{\mathrm{b}}$ & $2.13 \pm 0.47$ \\
\hline
\end{tabular}

${ }^{\mathrm{a}} \mathrm{P}<0.05,{ }^{\mathrm{b}} \mathrm{P}<0.01$ vs. control.

The results showed that a large number of cells treated with oridonin were positively stained by Annexin V-FITC (Fig. 2Bc-e). Which showed that oridonin was able to induce SGC-7901 cell apoptosis.

Oridonin induces early apoptosis rate of SGC-7901 cells. To quantify the apoptotic rate of oridonin on SGC-7901 cells, the Annexin V-FITC/PI staining and flow cytometry was adopted. The data obtained showed that oridonin induced early apoptosis of SGC-7901 cells in a dose-dependent manner (Fig. 3 and Table II). When the cells were treated with $0,20,40,80 \mu \mathrm{mol} / 1$ oridonin for $24 \mathrm{~h}$, the average proportion of Annexin V-staining positive cells and PI-staining negative cells (early apoptotic cells) significantly increased from $1.53 \% \pm 0.67 \%$ in control to $3.33 \% \pm 0.29,84.80 \% \pm 0.82$ and $96.43 \% \pm 0.51 \%$, respectively (Table I). Fig. 3B shows the graphic representation of the increase in the early apoptotic cells with increase in the dose of oridonin.

Oridonin affects apoptosis-associated protein expression in $S G C-7901$ cells. Whether or not oridonin induced apoptosis in SGC-7901 cell through the effects of apoptosis-associated protein, western blots were adopted to examined the protein expression of mitochondrial pathway of SGC-7901 cell treated with $2,4,8 \mu \mathrm{M}$ oridonin. The analysis results showed that all concentrations of oridonin $(2,4,8 \mu \mathrm{M})$ resulted in a significant increase of cytochrome c (Fig. 4A) and remarkable cleavage of caspases-3 were detected compared with the control group (Fig. 4B). Mitochondrial dysfunction is regulated by $\mathrm{Bcl}-2$ family proteins, thus the $\mathrm{Bcl}-2$ family proteins were examined in the study. Oridonin caused a significant reduction in Bcl-2 expression whereas the expression of Bax was significantly increased, which led to decrease of Bcl-2/Bax in a concentration-dependent manner (Fig. 4C). Thus, oridonin could induce apoptosis in SGC-7901 cells with mitochondrial pathway involved.

\section{Discussion}

Rabdosia rubescens are used in Chinese folk medicine for treatment of esophageal cancer in Taihang Mountains area of China for a long time. Research showed that oridonin was one of the most important antitumor active ingredient of Rabdosia rubescens (33-36). Our previous studies showed that 


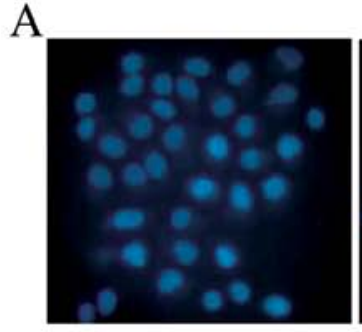

a

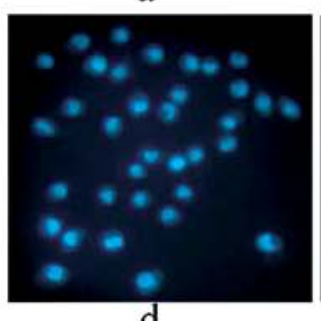

B

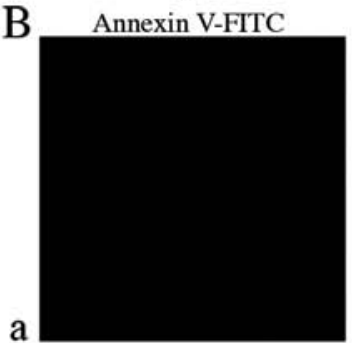

a
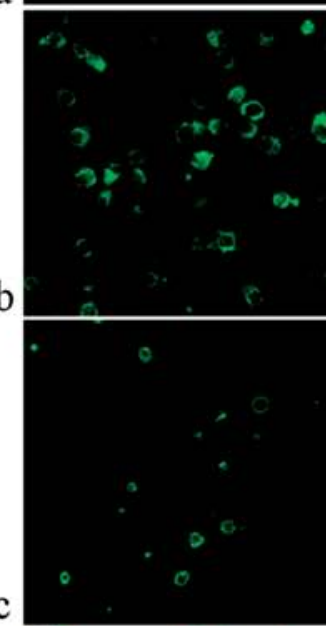

$\mathrm{c}$
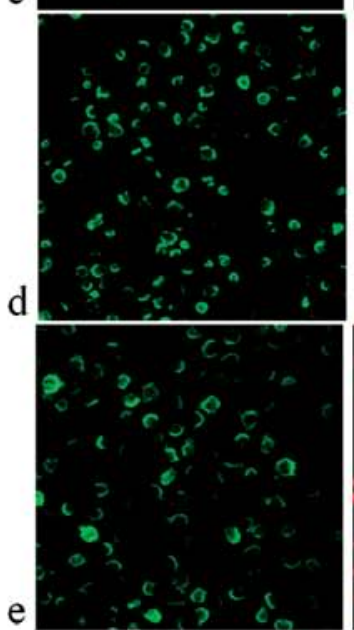

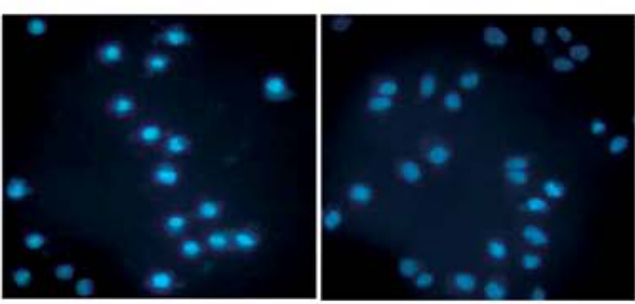

b

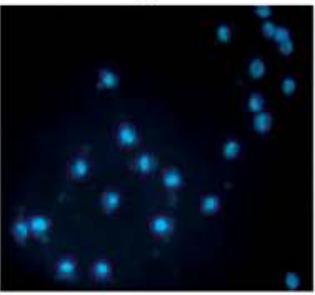

e
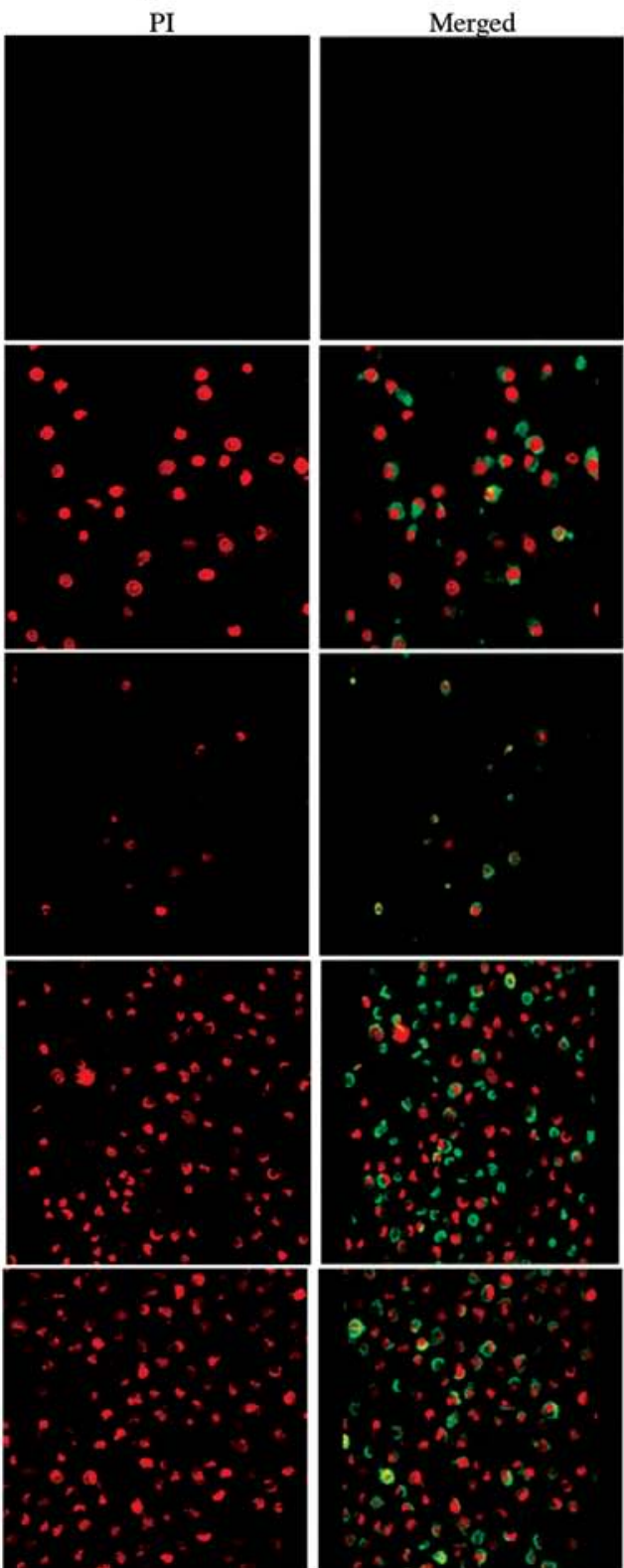

Figure 2. (A) The morphology of SGC-7901 cells exposed to oridonin for $24 \mathrm{~h}$ was observed under an inverted fluorescence microscope. Cells were treated with $0.1 \%$ DMSO (a), $18 \mu \mathrm{mol} / 1$ hydroxycamptothecin (b), $10 \mu \mathrm{M}$ oridonin (c), $20 \mu \mathrm{M}$ oridonin (d) and $40 \mu \mathrm{M}$ oridonin (e) for $24 \mathrm{~h}$, respectively (x400 magnification). (B) Detection of externalized phosphatidylserine by Annexin V-FITC in SGC-7901 cells after oridonin treatment for $24 \mathrm{~h}$. (a) Control, (b) $7 \mu$ M doxorubicin, (c) $10 \mu \mathrm{M}$ oridonin, (d) $20 \mu \mathrm{M}$ oridonin, (e) $40 \mu \mathrm{M}$ oridonin; first column represent cells stained with Annexin V-FITC. Second column represent cells stained with PI. Third column show fluorescence of Annexin V-FITC merged with PI staining. Control cells were treated with $0.1 \%$ DMSO, and the cells were treated with $0.1 \%$ DMSO and oridonin. 

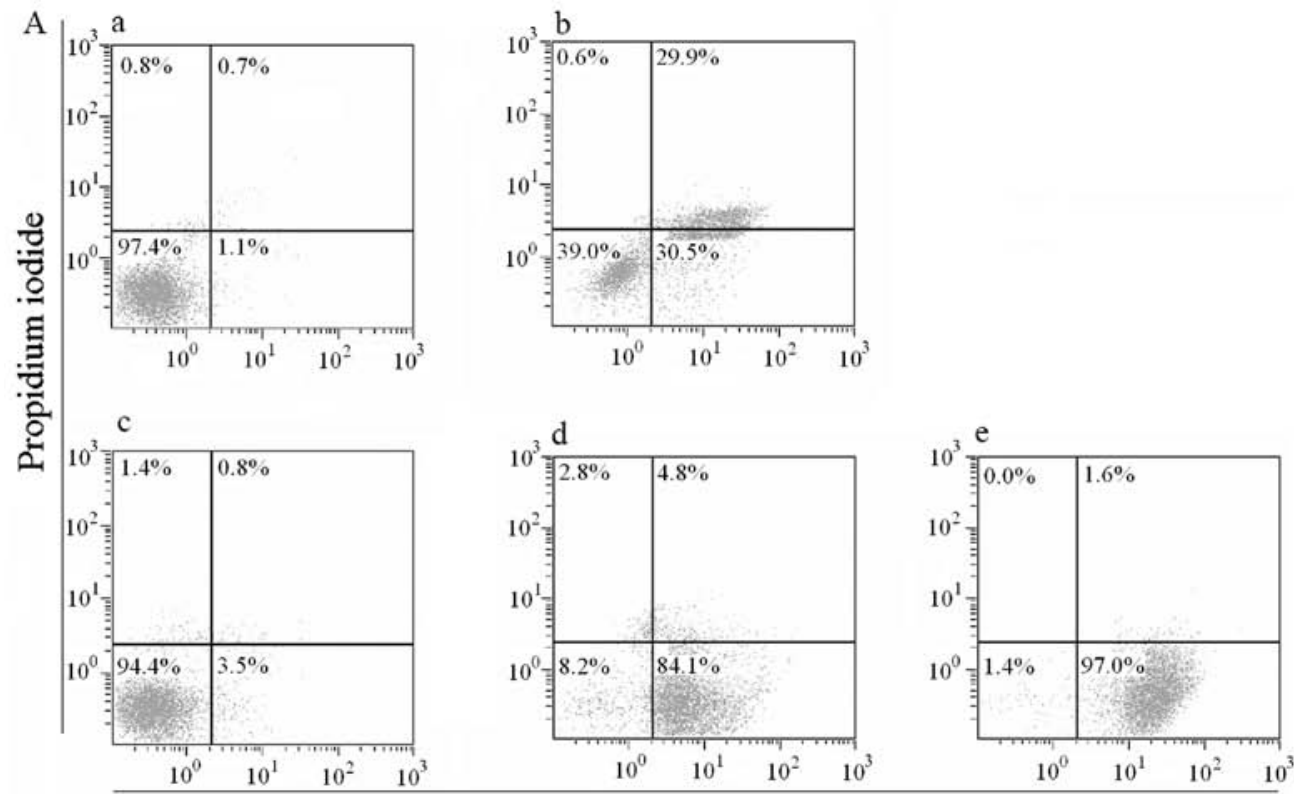

Annexin V-FITC

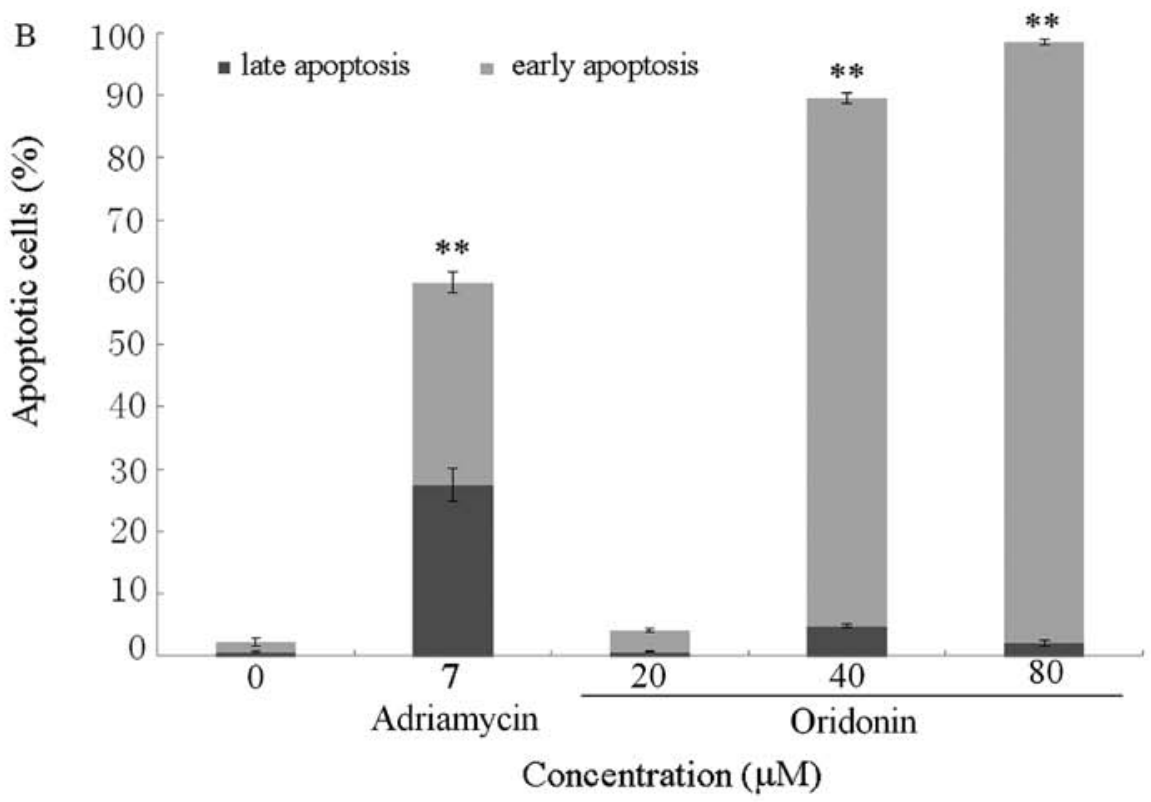

Figure 3. Oridonin-induced apoptosis in SGC-7901 cells using Annexin V-FITC/PI and flow cytometry. (A) Flow cytometric scatter diagram. Cell were treated with different concentrations of oridonin for $24 \mathrm{~h}$. (a) Control; (b) treated with $7 \mu \mathrm{M}$ doxorubicin; (c) treated with $10 \mu \mathrm{M}$ oridonin; (d) treated with $20 \mu \mathrm{M}$ oridonin; (e) treated with $40 \mu \mathrm{M}$ oridonin. (B) Columns show the mean values of three experiments (mean $\pm \mathrm{SD}$ ). ${ }^{* *} \mathrm{P}<0.01$, P-value compared with the control group.

oridonin could arrest the cell cycle in $\mathrm{G}_{2} / \mathrm{M}$ phase in human gastric cancer SGC-7901 cells (3). $\mathrm{G}_{2} / \mathrm{M}$ phase cell cycle arrest induced by oridonin would cause cell apoptosis, in order to confirm this hypothesis, we observed apoptotic effect of oridonin on SGC-7901 cells and the expression of apoptosis related protein, which has scarely been reported in SGC-7901 gastric cancer cells.

In the Hoechst 33342 assay, cells stained by Hoechst 33342 were observed by fluorescence microscopy, a classic method to distinguish apoptotic cells, normal cells and necrotic cells $(37,38)$. A small amount of Hoechst 33342 could penetrate the normal cell membranes and emit equivalent dark blue fluorescence after combination with DNA. However, lighter blue fluorescence was emitted in the apoptotic cells, because of membrane permeability enhancement, a large amount of Hoechst 33342 penetration, DNA breakage and function inactivation of P-glycoprotein. The fluorescence was darker in the necrotic cells than that in apoptotic cells because the structure of DNA of necrotic cells is unbroken. Thus, the fluorescence of apoptotic cells were lighter than that in the normal cells and the necrotic cells. As shown in Fig. 2Aa, cells of the control group had normal nuclear morphology under fluorescent microscope after Hoechst 33342 staining, indicating that the chromatin was equivalently distributed in the nucleus. The test group cells marked with irregular nuclei, crescent-shaped nuclei, condensation of chromatin and the morphological characteristics of apoptosis, which include emitting brighter fluorescence (Fig. 2Ac-e), were detected after treatment with 
A

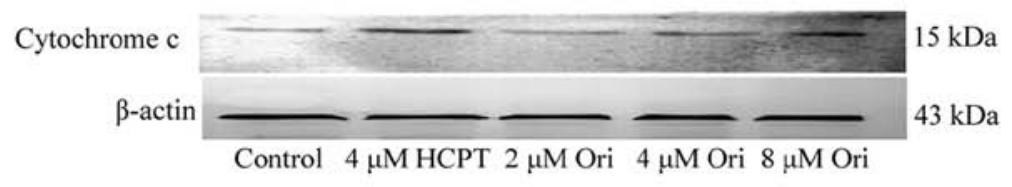

B
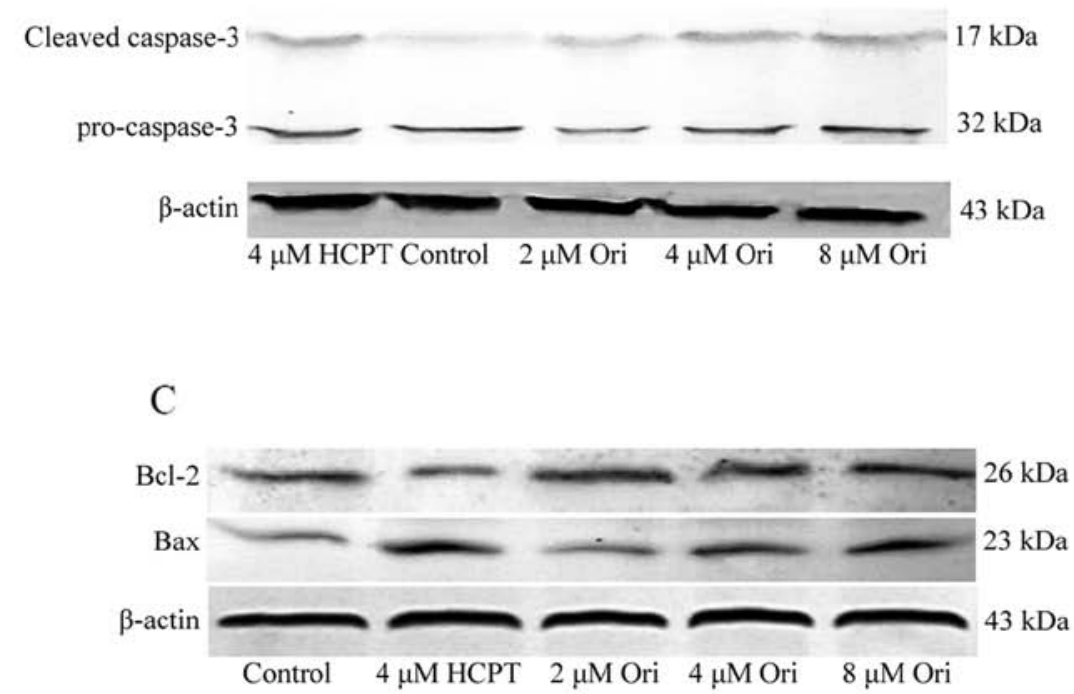
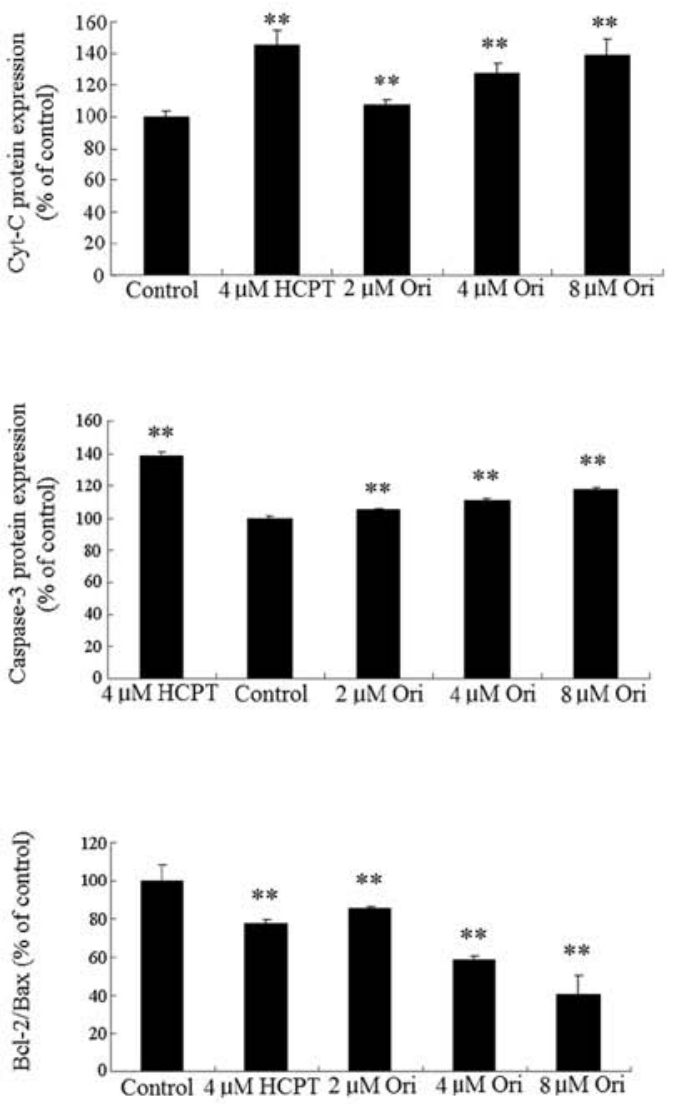

Figure 4. Effect of oridonin on apoptosis-related protein expression in SGC-7901 cells. SGC-7901 cells were treated with 2 , $4,8 \mu \mathrm{M}$ of oridonin for $24 \mathrm{~h}$ and then total proteins were quantitated and apoptosis-associated proteins were examined by western blot analysis as described in Materials and methods. (A) Cytochrome c, (B) caspase-3 and cleaved-caspase-3, (C) Bcl-2 and Bax. ${ }^{* *} \mathrm{P}<0.01$ compare with control group.

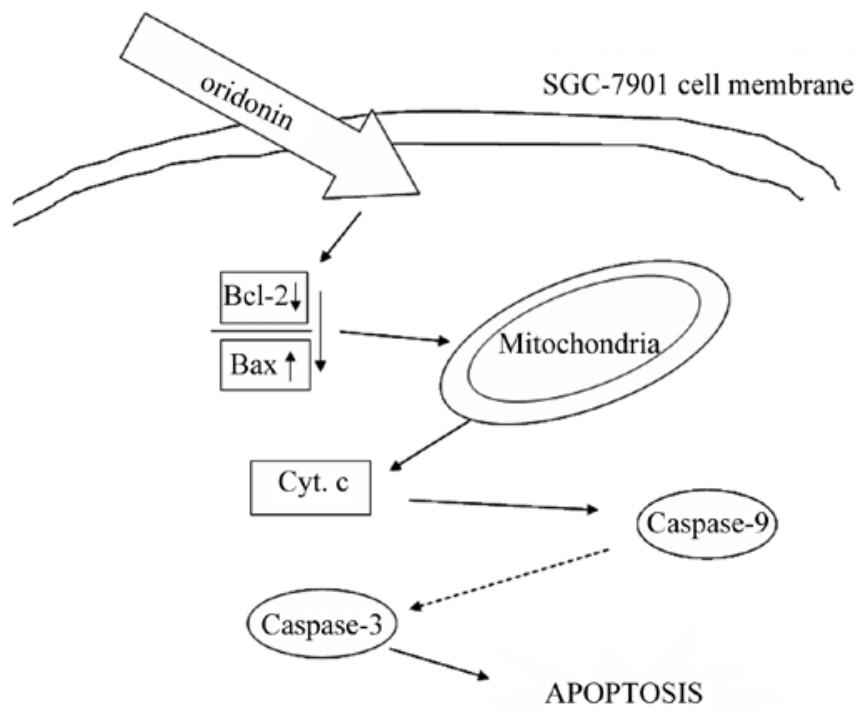

Figure 5. The possible signaling pathways for oridonin-induced apoptosis in SGC-7901 cells.

different concentrations of oridonin for $24 \mathrm{~h}$. These results indicated that oridonin is capable of inducing apoptosis in SGC-7901 cells.

In order to further evaluate whether oridonin could induce apoptosis in SGC-7901 cells, the cells were treated with the stain of Annexin V-FITC/PI and detected by confocal micros- copy. The results showed that a large number of cells treated by oridonin were positively stained by Annexin V-FITC (Fig. 2Bc-e), which showed that oridonin could induce SGC-7901 cell apoptosis. The conclusion was consistent with that detected by Hoechst 33342 assay.

After qualitative research of apoptosis induced by oridonin, cells stained with Annexin V-FITC/PI were detected by flow cytometer to quantify the early apoptotic rate induced by oridonin. The percentage of live, early apoptotic, late apoptotic and dead cells were calculated. The results showed that oridonin was able to induce apoptosis of SGC-7901 cells (Fig. 3 and Table II), which was visible from the percentage increase in mean fluorescence intensity in the early apoptotic stages of the treated cells when compared to the control.

It is well known that apoptosis can be regulated by apoptotic related protein. Bcl-2 family members and caspase family members play important roles in inducing cell apoptosis. The Bcl-2 family proteins, such as the anti-apoptotic protein bcl-2 and the pro-apoptotic protein bax, could enhance the membrane permeability of the mitochondria, which results in cytochrome c release from mitochondria to the cytoplasm (39). Cytochrome $\mathrm{c}$ is combined with apoptosis protease activating factor-1, recruits and cleaves procaspase-9, and activates caspase-3, which is responsible for apoptosis (40). In order to examine the underlying mechanism of apoptosis of oridonin, the respective expression of Bcl-2, Bax, cytochrome $\mathrm{c}$ and cleaved caspase- 3 was examined. 
Based on the results from western blot analysis, oridonin increased the protein expression of Bax, and decreased the protein expression of Bcl-2 (Fig. 4C). The ratio of $\mathrm{Bcl}-2 /$ Bax expression was decreased. Which led to cytochrome $\mathrm{c}$ release to the cytoplasm, as shown on the results (Fig. 4A) oridonin also increased the expression of cytochrome $\mathrm{c}$ in the cytoplasm in SGC-7901 cells. These observations suggest that oridonin induced apoptosis of SGC-7901 cells via mitochondria-dependent pathway.

Caspase-3, one of the family members of cysteinyl aspartate proteases, is an executioner enzyme inducing apoptosis (41). Mitochondrial pathway (42), death receptor-mediated pathway (43) and endoplasmic reticulum pathway (44) are the major signal transduction pathways that induced apoptosis $(45,46)$, which ultimately induce cell apoptosis by activating caspase-3 (47). We found that oridonin evoked caspase-3 activation, as evidenced by the appearance of $17 \mathrm{kDa}$ subunits, which showed that oridonin induced SGC-7901 apoptosis was caspase-3 dependent.

In conclusion, the possible significant molecular signal pathways for oridonin inducing apoptosis in SGC-7901 cells is shown in Fig. 5. Oridonin may decrease the ratio of Bcl-2/Bax, which lead to dysfunction of mitochondria and cause cytochrome $\mathrm{c}$ release, then activate the caspase- 3 leading to apoptosis. The present study demonstrated that oridonin induced apoptosis in SGC-7901 cells via the mitochondrial signal pathway, which may represent one of the major mechanisms of oridonin-mediated apoptosis in SGC-7901 cells.

\section{Acknowledgements}

This study was financially supported by Science and Technology Innovation Team Program in Higher Education Institutions of Heilongjiang Province (2014TD009), and the Program for New Century Excellent Talents in Heilongjiang Provincial University (1251-NCET-019), Science and Technology Research Project of Heilongjiang Province Department of Education (12541571).

\section{References}

1. Torre LA, Bray F, Siegel RL, Ferlay J, Lortet-Tieulent J and Jemal A: Global cancer statistics, 2012. CA Cancer J Clin 65: 87-108, 2015.

2. Fitzmaurice C, Dicker D, Pain A, Hamavid H, Moradi-Lakeh M, MacIntyre MF, Allen C, Hansen G, Woodbrook R, Wolfe C, et al; Global Burden of Disease Cancer Collaboration: The global burden of cancer 2013. JAMA Oncol 1: 505-527, 2015.

3. Gao SY, Li J, Qu XY, Zhu N and Ji YB: Downregulation of Cdk1 and cyclinB1 expression contributes to oridonin-induced cell cycle arrest at G2/M phase and growth inhibition in SGC-7901 gastric cancer cells. Asian Pac J Cancer Prev 15: 6437-6441, 2014.

4. Xu PY, Zhao GX and Chang LS: Local thermotherapy with rabdosia liquid as prophylactic measure for recurrence of superficial urinary bladder carcinoma: A non-randomized contemporary controlled study. Zhongguo Zhong Xi Yi Jie He Za Zhi 25: 1115-1117, 2005 (In Chinese).

5. Wang RL: A report of 40 cases of esophageal carcinoma surviving for more than 5 years after treatment with drugs. Zhonghua Zhong Liu Za Zhi 15: 300-302, 1993 (In Chinese).

6. Wang RL, Gao BL, Xiong ML, Mei QD, Fan KS, Zuo ZK, Lang TL, Gao GQ, Ji ZC, Wei DC, et al: Potentiation by Rabdosia rubescens on chemotherapy of advanced esophageal carcinoma. Zhonghua Zhong Liu Za Zhi 8: 297-299, 1986 (In Chinese).
7. de la Taille A, Hayek OR, Burchardt M, Burchardt T and Katz AE: Role of herbal compounds (PC-SPES) in hormone-refractory prostate cancer: Two case reports. J Altern Complement Med 6: 449-451, 2000.

8. Lou H, Gao L, Wei X, Zhang Z, Zheng D, Zhang D, Zhang X, Li Y and Zhang Q: Oridonin nanosuspension enhances antitumor efficacy in SMMC-7721 cells and H22 tumor bearing mice. Colloids Surf B Biointerfaces 87: 319-325, 2011.

9. Wang C, Jiang L, Wang S, Shi H, Wang J, Wang R, Li Y, Dou Y, Liu Y, Hou G, et al: The antitumor activity of the novel compound jesridonin on human esophageal carcinoma cells. PLoS One 10: e0130284, 2015.

10. Shen J, Zhang D, Zhao Z, Jia L, Zheng D, Liu G, Hao L, Zhang Q, Tian X, Li C, et al: Synthesis, characterization, in vitro and in vivo evaluation of PEGylated oridonin conjugates. Int J Pharm 456: 80-86, 2013.

11. Zhou GB, Kang H, Wang L, Gao L, Liu P, Xie J, Zhang FX, Weng XQ, Shen ZX, Chen J, et al: Oridonin, a diterpenoid extracted from medicinal herbs, targets AML1-ETO fusion protein and shows potent antitumor activity with low adverse effects on $\mathrm{t}(8 ; 21)$ leukemia in vitro and in vivo. Blood 109: 3441-3450, 2007.

12. Lou H, Zhang X, Gao L, Feng F, Wang J, Wei X, Yu Z, Zhang D and Zhang Q: In vitro and in vivo antitumor activity of oridonin nanosuspension. Int J Pharm 379: 181-186, 2009.

13. Wang CJ, Zhu GJ, Yu L and Shi BH: Preparation, in vitro, and in vivo antitumor activity of folate receptor-targeted nanoliposomes containing oridonin. Drug Dev Res 74: 43-49, 2013.

14. Ye LH, Li WJ, Jiang XQ, Chen YL, Tao SX, Qian WL and He JS: Study on the autophagy of prostate cancer PC-3 cells induced by oridonin. Anat Rec (Hoboken) 295: 417-422, 2012.

15. Ye YC, Wang HJ, Xu L, Liu WW, Liu BB, Tashiro S, Onodera S and Ikejima T: Oridonin induces apoptosis and autophagy in murine fibrosarcoma L929 cells partly via NO-ERK-p53 positive-feedback loop signaling pathway. Acta Pharmacol Sin 33: 1055-1061, 2012.

16. Yu Y, Fan SM, Song JK, Tashiro S, Onodera S and Ikejima T: Hydroxyl radical $(\cdot \mathrm{OH})$ played a pivotal role in oridonin-induced apoptosis and autophagy in human epidermoid carcinoma A431 cells. Biol Pharm Bull 35: 2148-2159, 2012.

17. Zang L, He H, Ye Y, Liu W, Fan S, Tashiro S, Onodera S and Ikejima T: Nitric oxide augments oridonin-induced efferocytosis by human histocytic lymphoma U937 cells via autophagy and the NF-кB-COX-2-IL-1 $\beta$ pathway. Free Radic Res 46: 1207-1219, 2012.

18. Liu Y, Liu JH, Chai K, Tashiro S, Onodera S and Ikejima T: Inhibition of c-Met promoted apoptosis, autophagy and loss of the mitochondrial transmembrane potential in oridonin-induced A549 lung cancer cells. J Pharm Pharmacol 65: 1622-1642, 2013.

19. Hsieh TC, Wijeratne EK, Liang JY, Gunatilaka AL and Wu JM: Differential control of growth, cell cycle progression, and expression of NF-kappaB in human breast cancer cells MCF-7, MCF-10A, and MDA-MB-231 by ponicidin and oridonin, diterpenoids from the chinese herb Rabdosia rubescens. Biochem Biophys Res Commun 337: 224-231, 2005.

20. Zhang T, Tan Y, Zhao R and Liu Z: DNA damage induced by oridonin involves cell cycle arrest at G2/M phase in human MCF-7 cells. Contemp Oncol (Pozn) 17: 38-44, 2013.

21. Wang H, Ye Y, Chui JH, Zhu GY, Li YW, Fong DWF and Yu ZL: Oridonin induces G2/M cell cycle arrest and apoptosis through MAPK and p53 signaling pathways in HepG2 cells. Oncol Rep 24: 647-651, 2010.

22. Qi X, Zhang D, Xu X, Feng F, Ren G, Chu Q, Zhang Q and Tian K: Oridonin nanosuspension was more effective than free oridonin on $\mathrm{G} 2 / \mathrm{M}$ cell cycle arrest and apoptosis in the human pancreatic cancer PANC-1 cell line. Int J Nanomed 7: 1793-1804, 2012.

23. Cheng Y, Qiu F, Ye YC, Tashiro S, Onodera S and Ikejima T: Oridonin induces $\mathrm{G} 2 / \mathrm{M}$ arrest and apoptosis via activating ERK-p53 apoptotic pathway and inhibiting PTK-Ras-Raf-JNK survival pathway in murine fibrosarcoma L929 cells. Arch Biochem Biophys 490: 70-75, 2009.

24. Kang N, Zhang JH, Qiu F, Chen S, Tashiro S, Onodera S and Ikejima T: Induction of $\mathrm{G}(2) / \mathrm{M}$ phase arrest and apoptosis by oridonin in human laryngeal carcinoma cells. J Nat Prod 73: 1058-1063, 2010.

25. Kang N, Cao SJ, Zhou Y, He H, Tashiro S, Onodera S, Qiu F and Ikejima T: Inhibition of caspase-9 by oridonin, a diterpenoid isolated from Rabdosia rubescens, augments apoptosis in human laryngeal cancer cells. Int J Oncol 47: 2045-2056, 2015. 
26. Pi J, Cai H, Jin H, Yang F, Jiang J, Wu A, Zhu H,Liu J, Su X, Yang P, et al: Qualitative and quantitative analysis of ROS-mediated oridonin-induced oesophageal cancer KYSE-150 cell apoptosis by atomic force microscopy. PLoS One 10: e0140935, 2015.

27. Yang J, Jiang H, Wang C, Yang B, Zhao L, Hu D, Qiu G, Dong X and Xiao B: Oridonin triggers apoptosis in colorectal carcinoma cells and suppression of microRNA-32 expression augments oridonin-mediated apoptotic effects. Biomed Pharmacother 72: 125-134, 2015

28. Bu HQ, Liu DL, Wei WT, Chen L, Huang H, Li Y and Cui JH: Oridonin induces apoptosis in SW1990 pancreatic cancer cells via p53- and caspase-dependent induction of p38 MAPK. Oncol Rep 31: 975-982, 2014.

29. Cai DT, Jin H, Xiong QX, Liu WG, Gao ZG, Gu GX and Qiu YH: ER stress and ASK1-JNK activation contribute to oridonininduced apoptosis and growth inhibition in cultured human hepatoblastoma HuH-6 cells. Mol Cell Biochem 379: 161-169, 2013.

30. Zhu M, Hong D, Bao Y, Wang C and Pan W: Oridonin induces the apoptosis of metastatic hepatocellular carcinoma cells via a mitochondrial pathway. Oncol Lett 6: 1502-1506, 2013.

31. Hsia TC, Yu CC, Hsu SC, Tang NY, Lu HF, Huang YP, Wu SH Lin JG and Chung JG: Cantharidin induces apoptosis of H460 human lung cancer cells through mitochondria-dependent pathways. Int J Oncol 45: 245-254, 2014.

32. Bradford MM: A rapid and sensitive method for the quantitation of microgram quantities of protein utilizing the principle of protein-dye binding. Anal Biochem 72: 248-254, 1976.

33. Meade-Tollin LC, Wijeratne EMK, Cooper D, Guild M, Jon E, Fritz A, Zhou GX, Whitesell L, Liang JY and Gunatilaka AAL: Ponicidin and oridonin are responsible for the antiangiogenic activity of Rabdosia rubescens, a constituent of the herbal supplement PC SPES. J Nat Prod 67: 2-4, 2004.

34. Wong AM, Zhang Y, Kesler K, Deng M, Burhenn L, Wang D, Moro A, Li Z and Heber D: Genomic and in vivo evidence of synergy of a herbal extract compared to its most active ingredient: Rabdosia rubescens vs. oridonin. Exp Ther Med 1: 1013-1017, 2010.

35. Ikezoe T, Yang Y, Bandobashi K, Saito T, Takemoto $\mathrm{S}$, Machida H, Togitani K, Koeffler HP and Taguchi H: Oridonin, a diterpenoid purified from Rabdosia rubescens, inhibits the proliferation of cells from lymphoid malignancies in association with blockade of the NF-kappa B signal pathways. Mol Cancer Ther 4: 578-586, 2005.
36. Chen S, Gao J, Halicka HD, Huang X, Traganos $F$ and Darzynkiewicz Z: The cytostatic and cytotoxic effects of oridonin (Rubescenin), a diterpenoid from Rabdosia rubescens, on tumor cells of different lineage. Int J Oncol 26: 579-588, 2005.

37. Kim KH, Kim JY, Kwak JH and Pyo S: Different anticancer effects of Saxifragifolin A on estrogen receptor-positive and estrogen receptor-negative breast cancer cells. Phytomedicine 22: 820-828, 2015

38. Krajarng A, Imoto M, Tashiro E, Fujimaki T, Shinjo S and Watanapokasin R: Apoptosis induction associated with the ER stress response through up-regulation of JNK in HeLa cells by gambogic acid. BMC Complement Altern Med 15: 26, 2015.

39. An T, Zhang Y, Huang Y, Zhang R, Yin S, Guo X, Wang Y, Zou C, Wei B, Lv R, et al: Neuregulin-1 protects against doxorubicininduced apoptosis in cardiomyocytes through an Akt-dependent pathway. Physiol Res 62: 379-385, 2013.

40. Nishida K, Yamaguchi O and Otsu K: Crosstalk between autophagy and apoptosis in heart disease. Circ Res 103: 343-351, 2008.

41. Mazur AJ,NowakD,MannherzHG and Malicka-Błaszkiewicz M Methotrexate induces apoptosis in CaSki and NRK cells and influences the organization of their actin cytoskeleton. Eur J Pharmacol 613: 24-33, 2009.

42. Kumar S, Yedjou CG and Tchounwou PB: Arsenic trioxide induces oxidative stress, DNA damage, and mitochondrial pathway of apoptosis in human leukemia (HL-60) cells. J Exp Clin Cancer Res 33: 42, 2014.

43. Tian CL, Wen Q and Fan TJ: Cytotoxicity of atropine to human corneal epithelial cells by inducing cell cycle arrest and mitochondrion-dependent apoptosis. Exp Toxicol Pathol 67: 517-524, 2015.

44. Broecker-Preuss M, Viehof J, Jastrow H, Becher-Boveleth N, Fuhrer D and Mann K: Cell death induction by the BH3 mimetic GX15-070 in thyroid carcinoma cells. J Exp Clin Cancer Res 34: 69, 2015.

45. Fulda S: Caspase-8 in cancer biology and therapy. Cancer Lett 281: 128-133, 2009.

46. Danial NN and Korsmeyer SJ: Cell death: Critical control points. Cell 116: 205-219, 2004.

47. Sun Y, Gao C, Luo M, Wang W, Gu C, Zu Y, Li J, Efferth T and $\mathrm{Fu}$ Y: Aspidin PB, a phloroglucinol derivative, induces apoptosis in human hepatocarcinoma HepG2 cells by modulating PI3K/ Akt/GSK3 $\beta$ pathway. Chem Biol Interact 201: 1-8, 2013. 